\title{
PENGARUH DISIPLIN BELAJAR DAN KINERJA TUGAS RUMAH TERHADAP HASIL BELAJAR FISIKA SISWA KELAS VIII SMP MUHAMMADIYAH 1 PEKALONGAN TAHUN PELAJARAN 2012/2013
}

\author{
Galih Ricky Utama \\ M. Barkah Salim \\ Pendidikan Fisika FKIP Universitas Muhammadiyah Metro \\ E-mail: barkah_um@yahoo.com
}

\begin{abstract}
Discipline is one thing that is important in achieving the maximum target in the learning process. Besides the performance of the task is an effort to instill a deeper concept in a subject matter. With the homework expected of students actively learn and be stimulated to enhance better learning, fostering initiative and are solely responsible bold. Sengganggnya so students use the time for things that support their learning by completing activities that are useful and constructive With discipline and performance of the duties expected student achievement in the field of study of physics can be optimal. The purpose of this study was to determine the effect of the discipline of learning and the performance of the duties of the learning outcomes of physics. This type of research is experimental . Collecting data using questionnaires and tests. The research was conducted at SMP Muhammadiyah 1 Pekalongan, randomly selected sample. The data analysis technique used is the calculation of the linear regression analysis . The results showed that the discipline of learning and administration tasks affect student learning outcomes, it is obtained from the results of hypothesis testing on the discipline of learning on learning outcomes in Fhit $=20.32$ greater than t table at significance level $\alpha=5 \% \mathrm{Fdaf}=4,10$. While testing the hypothesis on the performance of the duties of the student learning outcomes obtained with Fdaf value $=48.67$ greater than the significance level $\alpha=5 \%$ tdaf $=4.10$. After the authors conducted a study proved that the suspect had a significant influence between disciplines home learning and task performance on learning outcomes, the authors suggest to students to be more disciplined in learning activities, so that the learning outcomes that will be obtained will be better and in accordance with the expected. For teachers to further streamline the tasks given to the students, not just the task of completing a matter of course, but the task of creating a summary and demonstrate concepts learned in class.
\end{abstract}

Keyword : Discipline learning, homework performance, learning outcomes

\section{PENDAHULUAN}

Disiplin merupakan salah satu hal yang penting dalam mencapai target yang maksimal dalam proses pembelajaran.

Menurut

Gie

(1984:121) “disiplin dalam belajar adalah selain akan membuat seseorang memiliki kecakapan mengenai cara belajar yang baik dan sesuai dengan apa yang diharapkan juga merupakan suatu proses pembentukan watak yang baik dalam diri seseorang akan 
menciptakan pribadi yang

luhur".

Selain itu kinerja tugas rumah merupakan salah satu upaya untuk menanamkan konsep yang lebih dalam pada suatu materi pelajaran. Dengan adanya tugas rumah diharapkan siswa aktif belajar dan merasa terangsang untuk meningkatkan belajar yang lebih baik, memupuk inisiatif dan berani bertanggung jawab sendiri. Sehingga siswa memanfaatkan waktu sengganggnya untuk hal-hal yang menunjang belajarnya dengan mengisi kegiatan-kegiatan yang berguna dan konstruktif.

Menurut Roestiyah (2008: 133) "tugas rumah dapat dilakukan dengan memberikan tugas-tugas kepada siswa baik untuk di rumah atau yang dikerjakan di sekolah dengan mempertanggung jawabkan kepada guru". Dari pengertian di atas dapat dipahami bahwa, guru memberikan pekerjaan kepada siswa berupa soal-soal yang cukup banyak untuk dijawab atau dikerjakan yang selanjutnya diperiksa oleh guru.

Dengan disiplin dan kinerja tugas rumah diharapkan prestasi belajar siswa dalam bidang studi fisika dapat optimal.

\section{METODE PENELITIAN}

Rancangan penelitian dapat diartikan sebagai perencanaan untuk mengatur penelitian agar penelitian memperoleh data yang valid sesuai karakteristik variabel dan tujuan penelitian. Penelitian ini merupakan jenis penelitian korelasi untuk mengetahui pengaruh disiplin belajar dan kinerja tugas rumah terhadap hasil belajar siswa.

Rancangan penelitian adalah langkah yang harus ditempuh dalam melaksanakan penelitian, adapun langkah-langkah dalam penelitian antara lain sebagai berikut:

a. Persiapan, pada tahap ini penelitian melakukan pra survei ke lokasi yang akan dijadikan sebagai tempat penelitian. Disamping pra survei peneliti juga menyiapkan segala yang berkaitan dengan penelitian dan menyusun instrumen penelitian.

b. Pelaksanaan, pada tahap ini dilakukan pengumpulan data menggunakan angket dan metode tes. Dengan melaksanakan kegiatan pembelajaran di kelas VIII Semester genap SMP Muhammadiyah $\quad 1$ pekalongan.

c. Pengolahan data, pada tahap ini data dari hasil angket dan tes yang di peroleh diolah. Pemaparan yaitu berupa kata-kata yang 
berkaitan dengan hasil yang diberikan oleh siswa.

d. Menyimpulkan, mengambil keputusan terakhir dari data yang diperoleh dan sudah ada diolah oleh peneliti.

\section{HASIL DAN PEMBAHASAN}

\section{Disiplin \\ Belajar \\ terhadap Hasil Belajar Siswa}

Berdasarkan hasil

analisis diperoleh persamaan regresi linier sederhana $\hat{Y}=2,5+0,93 X \quad$ konstanta sebesar 2,5 menyatakan bahwa jika tidak ada kenaikan nilai dari variabel disiplin belajar siswa $\left(\mathrm{X}_{1}\right)$, maka hasil belajar (Y) adalah 0,93. Koefesien regresi sebesar 0,94 menyatakan bahwa setiap penambahan satu skor atau nilai disiplin belajar siswa akan memberikan kenaikan skor sebesar 0,75. Artinya jika disiplin belajar siswa $\left(\mathrm{X}_{1}\right)$ semakin tinggi maka nilai hasil belajar (Y) semakin tinggi pula, tetapi ada siswa yang mendapatkan nilai hasil belajar sedang dan tinggi. Sedangkan pada analisis uji independen terdapat $F_{\text {hit }}$ sebesar 20,32 dan pada taraf signifikansi $5 \%$ diperoleh $\mathrm{F}_{\text {daf }}$ sebesar 4,21 maka pada taraf signifikansi $5 \%$ menunjukkan $\mathrm{F}_{\text {hit }}>\mathrm{F}_{\text {daf. }}$ Sehingga hipotesis $\mathrm{H}_{0}$ ditolak (disiplin belajar tidak berpengaruh secara signifikan terhadap hasil belajar), dengan demikian terima $\mathrm{H}_{1}$ yang artinya koefesien regresi adalah signifikan. Kesimpulannya adalah disiplin belajar berpengaruh secara signifikan terhadap hasil belajar. Selanjunya untuk mengetahui jika disiplin belajar $\left(\mathrm{X}_{1}\right)$ tinggi maka nilai hasil belajar (Y) tinggi pula, untuk besar pengaruh disiplin belajar terhadap hasil belajar siswa ditunjukkan dengan koefisien regresi sebesar $r=0,57$ yang berada pada kategori tinggi dan koefisien determinan sebesar $r^{2}=0,3249$ artinya kontribusi disiplin belajar siswa sebesar $32,49 \%$ dalam meningkatkan hasil belajar fisika. Hasil selengkapnya dapat ditampilkan pada tabel sebagai berikut:

Tabel 1. Hasil Angket Disiplin Belajar Siswa

\begin{tabular}{|l|c|c|c|c|}
\hline Jo. & Interval (Skor) & Kategori & Frekuensi & Persentase (\%) \\
\hline 1. & $73-82$ & Tinggi & 8 & $28 \%$ \\
2. & $63-72$ & Sedang & 12 & $41 \%$ \\
3. & $53-62$ & Rendah & 9 & $31 \%$ \\
\hline
\end{tabular}


Tabel 2. Hasil Belajar Siswa

\begin{tabular}{|l|c|c|c|c|}
\hline No. & Interval (Skor) & Kategori & Frekuensi & Persentase (\%) \\
\hline 1. & $75-90$ & Tinggi & 8 & $28 \%$ \\
2. & $59-74$ & Sedang & 12 & $41 \%$ \\
3. & $33-58$ & Rendah & 9 & $31 \%$ \\
\hline
\end{tabular}

Klasifikasi: Tinggi, sedang, rendah berdasarkan Nurkancana dalam Ika (2010: 62)

Tabel 3. Daftar Siswa dalam Kategori Tinggi

\begin{tabular}{|c|l|c|c|}
\hline Nama Siswa & Kategori & $\begin{array}{c}\text { Disiplin } \\
\text { Belajar }\end{array}$ & $\begin{array}{c}\text { Hasil } \\
\text { Belajar }\end{array}$ \\
\hline AS & & 75 & 75 \\
AF & & 80 & 83 \\
AM & & 75 & 83 \\
FI & Tinggi & 77 & 75 \\
FIF & & 75 & 75 \\
MA & & 80 & 75 \\
YA & & 75 & 75 \\
YK & & 80 & 87 \\
\hline
\end{tabular}

Berdasarkan tabel 1 dapat diketahui bahwa siswa yang memiliki disiplin belajar dalam kategori tinggi yaitu sebesar $28 \%$, mereka memiliki sikap memanfaatkan waktu dan fasilitas belajar, menaati peraturan, mengerjakan tugastugas dan ujian, disiplin dalam usaha meningkatkan kemampuan dalam belajar yang tinggi. Hal tersebut berpengaruh positif terhadap hasil belajar yang didapatkan, dapat ditunjukkan pada tabel 3 bahwa siswa dengan memiliki disiplin belajar yang tinggi mendapatkan hasil belajar yang tinggi pula.

\section{Kinerja Tugas Rumah terhadap Hasil Belajar Siswa}

Berdasarkan hasil analisis diperoleh persamaan regresi linier sederhana $\hat{Y}=6,94+0,88 X \quad$ konstanta sebesar 6,94 menyatakan bahwa jika tidak ada kenaikan nilai dari variabel kinerja tugas rumah $\left(\mathrm{X}_{2}\right)$, maka hasil belajar (Y) adalah 0,88. Koefesien regresi sebesar 0,88 menyatakan bahwa setiap penambahan satu nilai kinerja tugas rumah akan memberikan kenaikan skor sebesar 0,88 . Artinya jika kinerja tugas rumah $\left(\mathrm{X}_{1}\right)$ semakin tinggi maka nilai hasil belajar (Y) semakin tinggi pula, tetapi ada siswa yang mendapatkan nilai hasil belajar sedang dan tinggi. Sedangkan pada analisis uji independen terdapat $F_{\text {hit }}$ 
sebesar 48,67 dan pada taraf signifikansi $5 \%$ diperoleh $\mathrm{F}_{\mathrm{daf}}$ sebesar 4,21 maka pada taraf signifikansi $5 \%$ menunjukkan $F_{\text {hit }}>F_{\text {daf. }}$ Sehingga hipotesis $\mathrm{H}_{0}$ ditolak (kinerja tugas rumah tidak berpengaruh secara signifikan terhadap hasil belajar), dengan demikian terima $\mathrm{H}_{1}$ yang artinya koefesien regresi adalah signifikan. Kesimpulannya adalah kinerja tugas rumah berpengaruh secara signifikan terhadap hasil belajar. Selanjutnya untuk mengetahui jika kinerja tugas rumah $\left(\mathrm{X}_{1}\right)$ tinggi maka nilai hasil belajar (Y) tinggi pula, untuk besar pengaruh disiplin belajar terhadap hasil belajar siswa ditunjukkan dengan koefisien regresi sebesar $r=0,80$ yang berada pada kategori tinggi dan koefisien determinan sebesar $r^{2}$ $=0,64$ artinya kontribusi kinerja tugas rumah sebesar $64 \%$ dalam meningkatkan hasil belajar fisika. Hasil selengkapnya dapat ditampilkan pada tabel sebagai berikut:

Tabel 4. Hasil Kinerja tugas rumah Siswa

\begin{tabular}{|l|c|c|c|c|}
\hline No. & Interval (Skor) & Kategori & Frekuensi & Persentase (\%) \\
\hline 1. & $73-86$ & Tinggi & 8 & $28 \%$ \\
2. & $59-72$ & Sedang & 15 & $52 \%$ \\
3. & $45-58$ & Rendah & 6 & $20 \%$ \\
\hline
\end{tabular}

Tabel 5. Hasil Belajar Siswa

\begin{tabular}{|l|c|c|c|c|}
\hline No. & Interval (Skor) & Kategori & Frekuensi & Persentase (\%) \\
\hline 1. & $75-90$ & Tinggi & 8 & $28 \%$ \\
2. & $59-74$ & Sedang & 12 & $41 \%$ \\
3. & $33-58$ & Rendah & 9 & $31 \%$ \\
\hline
\end{tabular}

Klasifikasi: Tinggi, sedang, rendah berdasarkan Nurkancana dalam Ika (2010: 62)

Tabel 6. Daftar Siswa dalam Kategori Tinggi

\begin{tabular}{|c|l|c|c|}
\hline Nama Siswa & Kategori & Iasil Belajar & $\begin{array}{c}\text { Kinerja } \\
\text { Tugas } \\
\text { Rumah }\end{array}$ \\
\hline AH & & 75 & 75 \\
AF & & 80 & 75 \\
AM & & 75 & 80 \\
FI & Tinggi & 77 & 75 \\
FIF & & 75 & 75 \\
MA & & 80 & 80 \\
YA & & 75 & 75 \\
YK & & 80 & 85 \\
\hline
\end{tabular}


Berdasarkan tabel 4 dapat diketahui bahwa siswa yang memiliki hasil tugas rumah dalam kategori tinggi yaitu sebesar $28 \%$, mereka dalam mengerjakan tugas rumah membuat rangkuman dan menyelesaikan soal dalam kategori yang tinggi, dalam artian siswa tersebut dalam kelompok yang memiliki hasil tugas rumah yang lebih baik. Hal tersebut berpengaruh positif terhadap hasil belajar yang didapatkan, dapat ditunjukkan pada tabel 6 bahwa siswa dengan memiliki nilai tugas rumah yang tinggi mendapatkan hasil belajar yang tinggi pula.

Berdasarkan analisis, diperoleh $\mathrm{F}_{\text {hit }}=16,38$ dengan $\mathrm{F}_{\mathrm{daf}}$ pada taraf signifikansi $5 \%=3,25$ dengan demikian $\mathrm{F}_{\text {hit }}>\mathrm{F}_{\text {daf }}$ sehingga hipotesis $\mathrm{H}_{0}$ (disiplin belajar dan kinerja tugas rumah tidak berpengaruh secara signifikan terhadap hasil belajar) ditolak dengan demikian terima $\mathrm{H}_{1}$, yang artinya koefesien regresi ganda adalah signifikan. Jadi, inteligensi disiplin belajar dan kinerja tugas rumah berpengaruh secara signifikan terhadap hasil belajar. Pembelajaran yang berlangsung terdapat beberapa kendala saat penelitian ini dilakukan antara lain masih terdapat beberapa siswa yang mengobrol meskipun dapat dikontrol oleh guru tidak dipungkiri bahwa waktu tidak bisa diefektifkan secara maksimal dan dalam kegiatan pembelajaran hanya beberap siswa yang aktif bertanya dan menyampaikan pendapat.

Secara umum pembelajaran yang telah dilakukan berjalan dengan baik, sehingga hasil dari analisis yang dilakukan sesuai dengan hipotesis yang telah diutarakan sebelumya. Berdasarkan penelitian tersebut disiplin belajar dan kinerja tugas rumah telah terbukti berpengaruh terhadap hasil belajar yang akan diperoleh siswa. Hal tersebut selaras dengan yang dikemukakan oleh Rohani (2004: 213) bahwa "usaha yang dilakukan seseorang untuk memperoleh suatu perubahan untuk bisa memahami, mengerti, dan menyesuaikan tingkah laku yang baru secara keseluruhan, sebagai hasil pengalamannya sendiri dalam interaksi dengan lingkungannya yang menunjukan nilai-nilai ketaatan, kepatuhan dalam proses belajar untuk memperoleh hasil yang bernilai dan lebih baik." Berdasarkan usaha disiplin tersebut siswa akan memperoleh hasil belajar yang lebih baik dengan semua ketaatan dan kepatuhan dalam belajar. Selain itu kinerja tugas rumah merupakan upaya yang baik dari guru agar siswa menjadi terprogram dalam menindaklanjuti kegiatan yang 
telah dilaksanakan di dalam kelas, dengan melakukan beberapa hal yang mendukung siswa seperti membuat rangkuman dan menyelesaikan soal. Hal tersebut selaras dengan apa yang telah dikemukakan oleh Sagala (2007: 219) bahwa: "Tugas rumah adalah cara penyajian bahan pelajaran dimana guru memberikan tugas tertentu agar murid melakukan kegiatan belajar, kemudian harus dipertanggungjawabkan. Tugas yang diberikan oleh guru dapat memperdalam bahan pelajaran, dan dapat mengecek bahan yang telah dipelajari. Tugas dan resitasi merangsang anak untuk aktif belajar baik secara individual maupun kelompok dengan harapan memperoleh hasil belajar yang baik."

\section{KESIMPULAN}

Berdasarkan analisis data dan pengujian hipotesis dalam penelitian ini, dapat disimpulkan bahwa:

a. Ada pengaruh yang signifikan antara disiplin belajar terhadap hasil belajar Siswa Kelas VIII SMP Muhammadiyah Pekalongan Tahun Pelajaran 2012/2013. Hal ini dapat dilihat dari analisis uji independen terdapat $F_{\text {hit }}$ sebesar 20,32 dan pada taraf signifikansi $5 \%$ diperoleh $\mathrm{F}_{\mathrm{daf}}$ sebesar 4,10 maka pada taraf signifikansi 5\% menunjukkan $\mathrm{F}_{\text {hit }}>\mathrm{F}_{\text {daf. }}$ Sehingga dapat dikatakan bahwa siswa yang memiliki disiplin yang tinggi maka hasil belajar juga akan tinggi.

b. Ada pengaruh yang signifikan antara kinerja tugas rumah terhadap hasil belajar Siswa Kelas VIII SMP Muhammadiyah Pekalongan Tahun Pelajaran 2012/2013. Hal ini dapat dilihat dari analisis uji independen terdapat $F_{\text {hit }}$ sebesar 48,67 dan pada taraf signifikansi $5 \%$ diperoleh $\mathrm{F}_{\text {daf }}$ sebesar 4,10 maka pada taraf signifikansi 5\% menunjukkan $\mathrm{F}_{\text {hit }}>\mathrm{F}_{\text {daf. }}$ Sehingga dapat dikatakan bahwa siswa yang memiliki kinerja tugas rumah yang tinggi maka hasil belajar juga akan tinggi.

c. Ada pengaruh yang signifikan antara disiplin belajar dan kinerja tugas rumah terhadap hasil belajar Siswa Kelas VIII SMP Muhammadiyah Pekalongan Tahun Pelajaran 2012/2013. Berdasarkan perhitungan pada taraf signifikansi $\alpha=5 \%$ diperoleh $F_{\text {hit }}=16,73$ dan $F_{\text {daf }}=3,25$ dengan demikian $F_{\text {hit }}>F_{\text {daf. }}$ Sehingga dapat dikatakan bahwa siswa yang memiliki disiplin belajar dan kinerja tugas rumah yang tinggi maka hasil belajar juga akan tinggi. 


\section{DAFTAR PUSTAKA}

Gie, The Liang. 1984. Cara

Belajar yang Efesien.

Jogjakarta : UGM

Sagala, Syaiful. 2007. Konsep dan

Makna Pembelajaran.

Bandung : CV Alfabeta

Rohani, Ahmad. 2004.

Pengolahan Pengajaran.

Jakarta: Rineka cipta

Roestiyah. 2008. Strategi Belajar

Mengajar. Jakarta: Rineka

cipta 